\title{
Rice Producers' Guide to Marketing Rice Straw
}

\author{
G. A. NADER, Farm Advisor, University of California Cooperative Extension Farm \\ Advisor, Sutter-Yuba Counties; P. H. ROBINSON, UCCE Specialist, Department of \\ Animal Science, UC Davis
}

\section{Markets for Rice Straw}

It is estimated that 3 to 5 percent of the rice acreage has straw baled for use later for various purposes (California Rice Commission 2009). The keys to marketing rice straw are identification of profitable uses for it and curing and packaging the straw in a manner that makes it most valuable to the client. Some growers have worked with end users to determine what type of processing makes the straw most valuable. Here are some of the uses for rice straw:

- dairy feed

- beef feed

- erosion control

- livestock bedding

- building construction

- mushroom production

\section{Important Field Management Considerations}

Consistent straw quality is very important to successful rice straw marketing. Producers who simply bale the harvester windrows need to work with their bankout drivers to make sure they do not run over the windrows. Areas that are smashed down by the bankout tires will not dry as quickly as the rest of the straw. This creates high-moisture "slugs" in the straw bales, and that can cause mold. If severe enough, the moisture can cause bales to spontaneously combust, destroying the straw and potentially setting fire to the straw storage area. If the movement of the bankouts is hard to control during harvest, consider raking the straw windrows so as to allow them to dry uniformly before baling. Although this added operation increases costs, it will improve the quality and consistency of the product. Most straw users prefer that baling occur when the moisture is as low as possible, except for beef cattle operations, which prefer some green color and a moisture content of 13 percent or less. 
Many rice producers are concerned that if they drain their fields early to allow for early baling they could reduce the quality of their rice crop. Choosing fields with well-drained soil or adding traction tires to the haying equipment can minimize the risk that rice grain quality will be reduced and at the same time ensure that the secondary straw crop will retain its optimum forage value.

\section{Rice Straw Removal Costs}

Most rice growers think about the baling and hauling costs of straw removal to determine whether it is a cost-effective method of straw management for their operation. Surveys of rice growers indicate wide variations in the cost of baling and stacking rice straw. The two major factors affecting price are the size of the bale and ownership of the harvesting equipment. Larger bales cost less to remove than three-twine bales. Which bale size will be most salable depends on your market. Growers who use their own haying equipment have reported lower costs than those who have the straw custom baled and stacked. Most growers put their focus on harvesting the rice grain and prefer not to add the responsibility of managing two operations (i.e., grain and straw) at the same time.

In addition to the costs of baling and stacking rice straw, there are also costs associated with nutrient losses from the field when you remove straw rather than incorporate it into the soil. Burning rice straw volatizes most of its nitrogen and sulfur, which is then lost to the atmosphere, while most of the potassium remains on the soil in the ash. Straw removal takes away potassium and nitrogen as well as sulfur. In contrast, most nutrients are retained in the soil when the straw is incorporated into the soil. Growers need to weigh these different nutrient impacts when they consider the costs and benefits of producing rice straw.

The typical nutrient content of rice straw, based on 100 percent dry matter as reported by Summer and Williams (2001), are 0.7 percent nitrogen $(\mathrm{N})$ and 1.7 percent potassium $(\mathrm{K})$. Research by Nader and Robinson (2004) on rice straw sampled from 77 different stacks collected over 2 years reported similar $\mathrm{N}$ and $\mathrm{K}$ levels in rice straw, in addition to values of most other nutrients (table 1).

Rice growers report that when they bale harvester windrows cut at the waterline, their fields yield an average of 1.5 tons of straw per acre. Most straw is baled at 6 to 10 percent moisture. Table 2 shows the average loss in nutrients from a field at four different straw removal rates. The data in table 2 assume the straw is baled at 6 percent moisture and that 100 percent of the nitrogen and potassium in the straw is recycled by incorporation.

Table 1. Concentration (\%) of selected nutrients in rice straw collected at several locations.

\begin{tabular}{|lcccccccc|}
\hline \multirow{2}{*}{$\begin{array}{l}\text { Concentration } \\
\text { level }\end{array}$} & \multicolumn{5}{c|}{ Nutrient concentration (\%) in rice straw } \\
\cline { 2 - 9 } & Nitrogen & Potassium & Calcium & Phosphorus & Magnesium & Sulfur & Sodium & Chloride \\
\hline Average & 0.77 & 1.74 & 0.30 & 0.10 & 0.20 & 0.08 & 0.15 & 0.52 \\
Maximum & 1.12 & 2.70 & 0.50 & 0.17 & 0.30 & 0.15 & 0.50 \\
Minimum & 0.53 & 1.10 & 0.19 & 0.05 & 0.12 & 0.04 & 0.01 \\
\hline
\end{tabular}


Table 2. Average nutrient loss at different straw removal rates.

\begin{tabular}{|c|c|c|c|c|}
\hline \multirow[b]{2}{*}{ Nutrient } & \multicolumn{4}{|c|}{ Tons of straw removed per acre } \\
\hline & 1 & 1.5 & 2 & 3 \\
\hline $\begin{array}{l}\text { Nitrogen (lb) removed } \\
\text { per acre }\end{array}$ & 14.5 & 21.7 & 29 & 43.4 \\
\hline $\begin{array}{l}\text { Phosphorus (lb) } \\
\text { removed per acre }\end{array}$ & 1.9 & 2.8 & 3.8 & 5.6 \\
\hline $\begin{array}{l}\text { Potassium (lb) removed } \\
\text { per acre }\end{array}$ & 32.7 & 49.1 & 65.4 & 98.1 \\
\hline
\end{tabular}

\section{Straw Harvest Options for Different Markets}

Each straw market has different preferences for how the straw should be produced. The method of preparation will limit the range of customers and the markets that may be interested in a grower's straw. Dairies and erosion control users, for instance, prefer a shorter straw length, while mushroom producers prefer longer straw.

Producers use a variety of methods for straw management:

1. Straw walker harvester. Straw is baled in the windrows for a long-stem product. If baled and stacked with green color, this is an appealing product for beef operations and for mushroom production.

\section{Rotary-style harvester with straw choppers.}

This can shred the straw to varying extents, depending on the make of harvester and its ground speed during harvest. The resulting windrows are baled. If the equipment is set to produce a straw length of less than 4 inches, it can be used as both dairy feed and erosion waddles.

3. Flail chopping. Equipment chops the dried windrows of straw to reduce stem length before baling. Growers report that chopping the straw at a higher moisture content increases the equipment's horsepower requirement. This method produces straw that can be used as beef cow feed.
A demonstration project found that it produced a straw that is not optimal as diary feed. Flail-chopped straw can also be dropped in a net from a helicopter to provide area mulch for erosion control.

4. Cutter baler. The baler is equipped with a cutter apparatus that slices the straw into 4to 6-inch lengths. The addition of the cutter increases the baler's horsepower requirement and reduces its daily operation output. Using this equipment with higher-moisture straw increases the resulting straw length, regardless of the number of knives activated. Straw produced by this method is preferred by dairies and erosion waddle users since it saves them the costs of chopping the straw themselves and avoids dust issues that arise when they do the chopping themselves. Like flail-chopped straw, cutter-baler straw can also be dropped in a net from a helicopter to provide area mulch for erosion control.

5. Swathing. This usually means cutting the plant near ground level and then baling and removing all of the straw. The plant material that grew below the rice field's water line is more coarse and can have sediments attached to the exterior of the plant. Both of these attributes make it less attractive to livestock operations. 
If rain falls on the straw, consider using a rake after the top of the windrow has dried to roll the straw over so it can dry on both sides. This is especially important in October, when the days are cooler and shorter than in September. Without raking, high moisture in the bottom of the windrow can allow mold growth, which will limit the potential uses of the straw.

\section{Selling the Straw}

Some rice straw producers advertise on the Rice Straw Market Web site (http://www. ricestrawmarket.org), while others work directly with end users or advertise their straw in trade publications. Baling the rice straw after a buyer has made a down payment or contracted to purchase the straw is the best plan. A policy of "bale it and they will come" can be very costly to the grower. If the rice producer does not have a contract from the customer, he or she should consider getting a bill of lading signed by the truck driver before the straw leaves the field. Hay growers have long used a bill of lading to secure payment obligations before shipping. Some growers request a deposit before they will bale and further payment before they will ship.

\section{Potential Markets}

There are several existing uses for rice straw that a producer can target before the straw is baled. Two of these are feed markets-for dairy and beef cattle-and the products that each needs are very different. Rice growers need to understand these differences to successfully sell straw each year into either of these markets.

\section{Dairy Replacement Heifer Feed}

Wheat straw is traditionally used in California replacement heifer rations, as it breaks up without chopping during the feed ration mixing process. As rice straw does not break up during the mixing process, the key to displacing wheat straw in this market is to deliver rice straw with a straw length of 4 to 6 inches so it can be mixed directly into a Total Mixed Ration (TMR) without chopping at the dairy or added mixing time. Rice straw that has not been sliced or chopped to reduce its stem length to 4 to 6 inches should not be sold to dairies unless they plan to chop it before mixing into their TMR. Straw longer than 6 inches will cause an unevenly mixed TMR and longer mixing time, and the straw can wrap around shafts and break parts on the TMR mixer.

Dairy owners and nutritionists generally deem long rice straw to be too expensive to feed at any price because it is so important that the heifers be fed an evenly mixed TMR on a regular basis. For example, if it takes dairy feeders 10 minutes more per load to mix untreated straw and they need to feed their stock 10 loads per day, that adds up to more than 1.5 additional hours' feeding per day, an unacceptable addition for most dairy operations. All of this points to the need to define and deliver a product that fits the individual user's needs. In the case of dairies, that means dry straw with a stem length of 4 to 6 inches.

Many rice growers already own a flail chopper and are not interested in contracting for or purchasing a cutter baler. In a dairy demonstration of flail-chopped rice straw added at 2 to $3 \mathrm{lb}$ per head per day, dairy operators encountered incomplete TMR mixing as the straw formed balls ( figure 1) and cows sorted the rice straw away from the rest of the feed and refused to eat it ( figure 2). At the $5 \mathrm{lb}$ per head per day, it greatly increased mixing time. Flail chopping and baling at 10 percent moisture or less may reduce some of these problems because the drier the straw is for flail chopping, the more the straw length is reduced. 


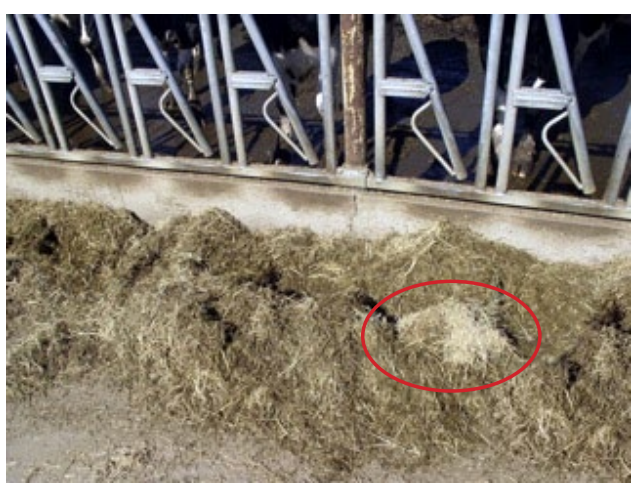

Figure 1. Flail-chopped rice straw does not mix evenly with other total mixed ration (TMR) components (note the clumping in the circled area).

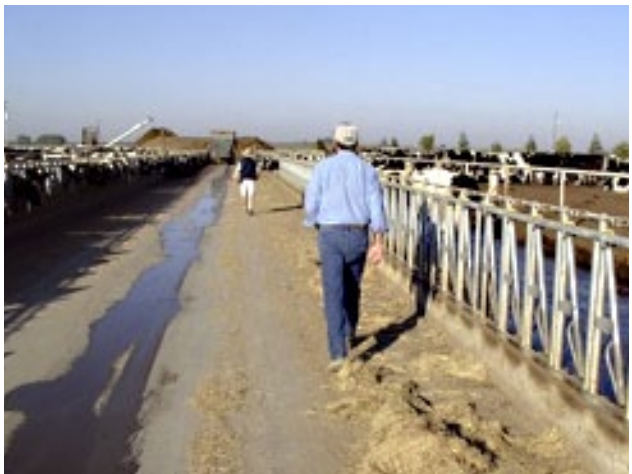

Figure 2. Heifers have refused this flailchopped rice straw from the total mixed ration (TMR) fed 24 hours earlier.

Rice straw has great potential for use in rations for dairy replacement heifers. Rice straw can supply them with a lower-cost forage that stimulates rumen development and provides bulk that limits total feed intake. The potential of this market can be determined on the basis of the number of heifers raised in dry lots and their daily consumption potential. In 2008, for example, there were approximately one million dairy replacement heifers in California and about 85 percent of them were fed a TMR in dry lots. Rice straw feeding demonstrations conducted by UC Cooperative Extension showed that rice straw baled with a cutter baler with less than 12 percent moisture

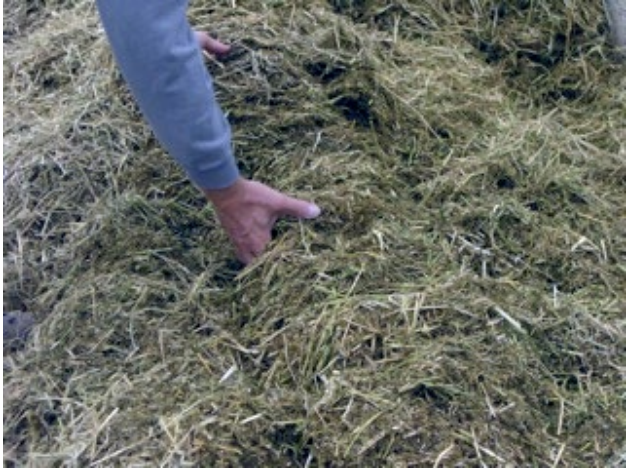

Figure 3. Cutter-baled rice straw mixes evenly into a dairy heifer total mixed ration (TMR).

could be fed at a rate of 2 to $4 \mathrm{lb}$ per head per day when combined with other feeds in a TMR mixer wagon ( figure 3).

If dairy operators can obtain a consistently chopped product that they can add directly to the TMR mixer, its use will increase. Most dairies' feed purchases are controlled in part by consulting nutritionists, each of whom may work for 5 to 20 dairies. Rice growers should work directly with the dairy owner or nutritionist to understand their needs and provide a direct market for the straw. Hay brokers provide another route for selling into the dairy market. Most are bonded by the California Department of Food and Agriculture and a list of bonded brokers is available online from the CDFA's Market Enforcement Division (http://www.cdfa.ca.gov/mkt/meb/).

\section{Beef Cattle Feed}

Rice straw is often used by beef cattle operations as a dry matter supplement to pasture feeding during fall and winter. Beef operations are more interested in the nutritional quality of the straw than are dairies. They prefer straw that is baled while it has some green color with a little more moisture (10 to 13\%). Since beef operations do not mix the straw with other feeds, it is important that the cattle find it sufficiently attractive in flavor so that they will want to consume it. 
In the Sacramento Valley area, cattle ranchers spread the large bales out on the range in fall and allow the cattle to graze the range and feed on the bales to meet their nutrient needs, thereby extending the carrying capacity of the pasture. Most cattle ranchers would rather not have small bales because they cost more to handle.

In the intermountain area of California, Oregon, and Nevada, cattle are brought into hay lots and fed there for the winter. Ranchers feed them rice straw along with alfalfa and other hays to reduce the cost of feeding spring-calving cows before calving, while their nutritional requirements are lower. Interest in rice straw in this area is generally highest during drought, when hay availability is limited and feed prices are higher. Transportation is the major cost for these operations when they use rice straw, but costs can be kept down if they use back hauls on trucks that have carried alfalfa hay down to San Joaquin Valley dairies. The size of this market for rice straw is regulated by the costs of other feeds (i.e., grain and hay) and the amount of rainfall for irrigation on hay fields and rangeland forage production areas.

\section{Management Actions That Can Impact Forage Value}

The number of days that a rice grower waits between grain harvest and straw baling impacts the palatability and quality of the forage. Rice straw that is baled 1 to 3 days after harvest maintains the best palatability (i.e., smell, flavor, and color). Forage quality starts to decrease at 6 to 10 days after harvest (Nader, Williams, and Ingram 1998). Research has shown that as rice straw dries, its digestibility also declines by 20 to 30 percent from the time of grain harvest to the time when the field-dried straw reaches 10 percent moisture. One approach is to let the straw dry less and so improve its digestibility for cattle (Nader and Robinson 2009). Indeed, beef cattle digest a 13 percent moisture straw more easily than a 6 percent moisture straw. Moisture content levels above 15 percent at baling should be avoided, since they facilitate formation of mold after baling. Straw management is much different for dairy feeders, where a lower straw moisture content is desirable because it improves the mixing of the straw into the TMR.

Research has shown that the higher the nitrogen fertilization of rice crops, the higher the crude protein content of straw (Nader and Robinson 2000). This is not intended to be a recommendation that rice growers increase nitrogen applications to improve forage quality. It should only be used as a strategy to help the grower select the higher-fertility fields for potential use as sources of livestock feed and to make clear that there is a very high correlation between the level of nitrogen fertilization and the crude protein content of the resulting straw.

Head moisture is highly correlated to a rice plant's maturity. The higher the rice head moisture at harvest, the higher the digestibility of the straw. As the rice plant matures, the digestibility of the rice straw declines. This is why cold-water checks (where the water is colder because it comes directly from the irrigation ditch) and rice harvested at higher head moisture result in straw with a higher nutritional quality.

\section{High Variability in Nutritional Quality}

Rice straw varies greatly in its feeding value, with crude protein (CP) values from 2 to 7 percent and acid detergent fiber (ADF) values from 46 to 56 percent. No research has completely explained the reasons for this variability, but some of the factors that may influence quality include days between grain harvest and baling, nitrogen fertilization, soil type, and rice variety. Figures 4 and 5 summarize three years' nutritional variations for 133 different stacks of rice straw from across Northern California. Each year's rice straw differed in quality, and in 2008 the $\mathrm{CP}$ and $\mathrm{ADF}$ were both much lower than in other years. ADF is a laboratory- 
determined value that indicates fiber content and can help predict the digestibility of any feed. In general, the lower the $\mathrm{ADF}$, the more digestible the feed is. A non-lactating beef cow requires a diet containing 7 percent crude protein (National Research Council). The lower the CP content of the straw, the higher the cost will be to add in other feeds or supplements to meet the cattle's nutrient requirements.
The University of California has developed nutrient testing recommendations for rice straw to enable purchasers to optimize the performance of their beef cattle when rice straw is a part of their diet. Suggested forage value criteria for rice forage for beef cattle are 4.5 percent or higher for CP, 50 percent or lower for ADF, and 15 percent or lower for moisture.
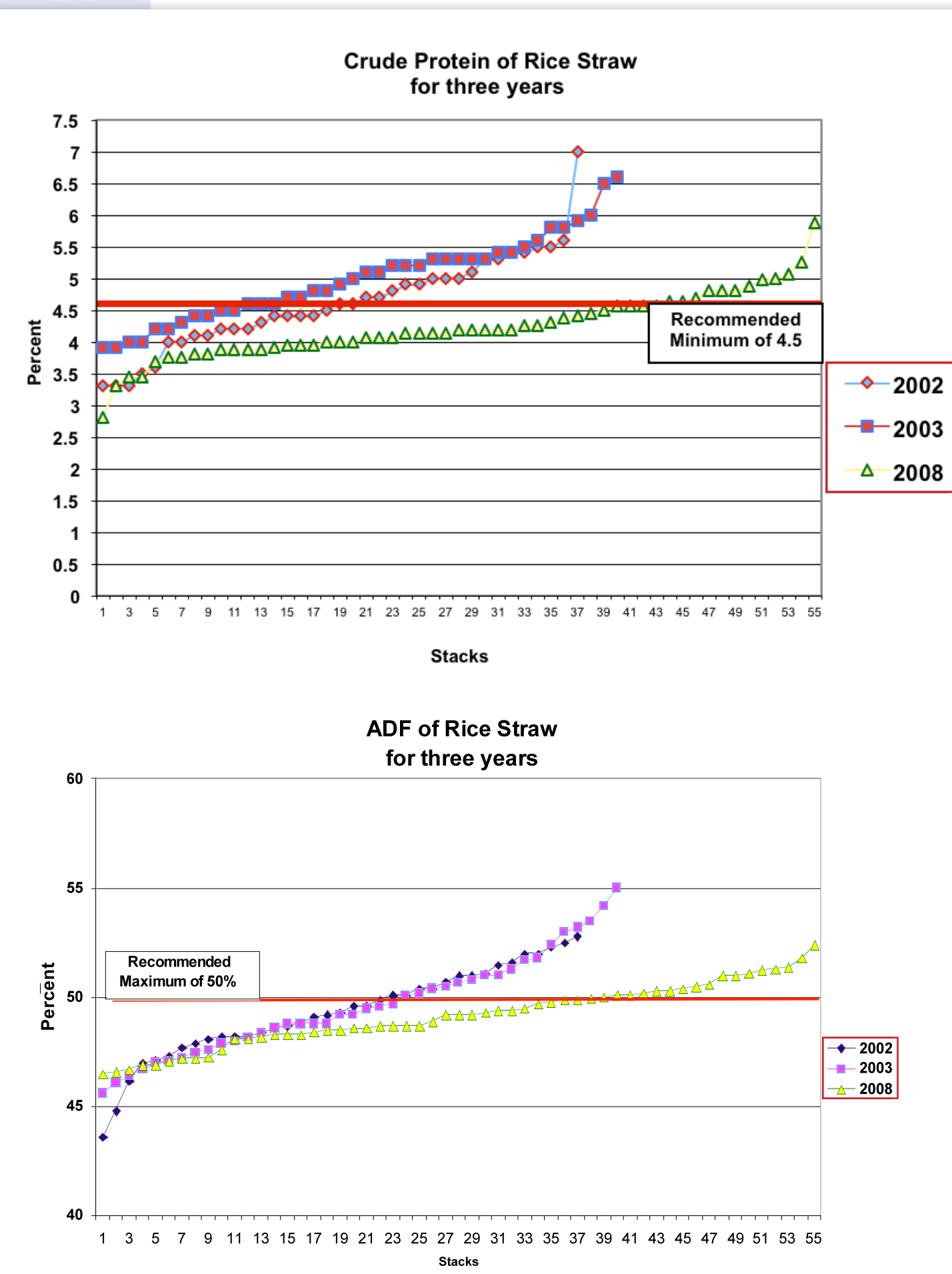

Figure 4. Variations in crude protein (CP) levels in rice straw samples collected from 56 different stacks in three different years.

Figure 5. Variations in acid detergent fiber (ADF) levels in rice straw samples collected from 56 different stacks in three different years. 


\section{Sampling before Grain Harvest to Estimate Forage Quality at Baling}

Most rice straw producers only bale fields that they believe will yield higher-quality straw, based on higher application rates for nitrogen fertilizer, growth in cold-water checks, or harvest at higher head moisture due to early plant maturity for that variety. They could do a better job of addressing their livestock markets' needs and improve their product by adding sampling processes for the straw before harvest to give them a better idea of which fields have produced straw that is the best for cattle feed. Research data from Nader, Williams, and Ingram (1998) can be used to estimate the loss of nutritional value between the time of sampling (18 or 12 days before harvest) and the time of baling, and so estimate the final crude protein (CP) and acid detergent fiber levels of the straw:

- If a straw sample is collected 18 days before harvest, assume a 1.8 percent reduction in $\mathrm{CP}$ and 2.2 percent increase in ADF.

- If a straw sample is collected 12 days before harvest, assume a 1.25 percent reduction in $\mathrm{CP}$ and 0.4 percent increase in $\mathrm{ADF}$.

To collect a straw sample for analysis, walk randomly across the field, cutting plants at the height of expected harvest. Strip the grain from the head, place the remaining straw in a paper sack, and dry it for 2 to 3 days at ambient temperature or for 24 hours in an oven set below $90^{\circ} \mathrm{F}$. Once the sample is dry, ship it to the laboratory with a request for crude protein and acid detergent fiber analysis. Take a separate sample from each field that has a different variety, soil, or nitrogen fertilizer regime. If straw quality assessment values deviate significantly from the quality criteria, consider baling the straw for other, non-feed uses or incorporating it into the soil.

\section{Sampling Stacks of Straw}

If you are sampling the stack of baled straw after harvest to determine if it meets quality specifications, take core samples from at least 20 bales and place them in a labeled, sealed zip-top plastic bag for delivery to the laboratory for analysis. You should be able to buy a haysampling probe locally or through your haytesting laboratory. Have the samples analyzed for moisture, $\mathrm{CP}$, and ADF. You can find more information on forage testing processes and equipment online at the National Forage Testing Association Web site (http://www.foragetesting. org/index.php?page=forage_sampling).

\section{Label Restriction for Straw Used for Livestock}

Read the label on any herbicide, desiccant, or pesticide you apply to your rice crop and check with your supplier to see if its use restricts your ability to sell the straw for feed.

Animal bedding. Application of straw to soil at dairies and feedlots as a way to help preserve and dry the soil is a well-established, longstanding use of rice straw. Dairy operations spread the straw throughout these areas so the animals will be able to lie down on dry bedding during winter. The ease with which bales can be broken open into flakes of straw and spread around is an important factor for buyers. Flailchopped or baler-sliced product will break up and spread more easily, but dry, long-stem straw is more resistant to trampling into the mud.

Erosion control. The most important requirement for the erosion-control market is weed-free certification for the straw. Because rice straw is produced in an aquatic environment, it is preferred for erosion control; it does not pose a risk of introducing upland weeds, unlike wheat or barley straw. Another advantage of rice straw is that it has a high silica content that tends to make rice straw last longer in the environment than other straws. For more information on the weed-free certification process, contact the California Rice Commission's Straw Certification Program (http://www.calrice.org, [916] 929-2264). 


\section{Post-Fire Watershed Protection}

After a devastating wildfire, rice straw can help protect soil and water quality from erosion damage in winter rains. The straw is spread on the surface of the ground, either by crews working by hand or by helicopter drop, replacing the burnt-off organic matter or litter that normally would protect the surface of the soil from being washed into rivers and streams during winter rains. Information on hand application of straw mulch around the home after a wildfire is available online (http://ftp-fc.sc.egov.usda. gov/CA/programs/EWP/2007/FS55.pdf).

Bales of rice straw that has been sliced or flail chopped will spread the best in an aerial application. Bales are placed in a net, their twine is cut, and the net is lifted by a helicopter and carried over the burn-damaged site where the straw is released from the net. The straw spreads out as it falls to the ground and provides wide coverage and protection. This method is much cheaper than spreading by hand. More information on aerial mulching is available online (http://www.fs.fed. us/psw/publications/documents/psw_gtr189/ psw_gto189_091-098_faust.pdf).

Bales can also be used to make check dams in draws and seasonal streams to decrease the transport of post-fire debris down to flowing streams. Bales have commonly been used for erosion control by cutting strategic drainage trenches and then staking the bales into place at key locations along drainages and at other sites susceptible to erosion. For this application, users fix the bales in place by driving metal or wooden stakes through the bale and into the ground. A common arrangement puts the bales at angles to create a catch basin that collects silt and other sediments for a period of time. Details of construction can be found online (http://www. mt.nrcs.usda.gov/technical/fires/strawdam.html).

\section{Construction}

Rice straw is also used in construction areas to protect bare soil surfaces from soil loss. Netted rolls stuffed with rice straw (wattles) are placed at the edge of the construction site to trap soil on the site. Erosion blankets ( flattened netted sacks filled with rice straw) are also placed on bare soil surfaces after construction. Chopped or baler-sliced straw allows for direct placement of the straw into the netting. Another construction site practice is to apply straw that has been chopped into very fine pieces and combined with a tackifier or binding agent that causes the straw to adhere to the soil surface to reduce soil losses during storms.

Housing. Bales of straw can be used in walls during construction to provide insulation. The bales are placed between the wood or steel support beams between the interior and exterior walls. Use of straw bales in house construction increases insulation and decreases eventual heating and cooling costs. The best product for this purpose is tightly baled straw without mold or "green slugs," in 3-twine-sized bales of consistent length, kept dry from baling to delivery, and with as little grain content as possible. More information on this market is available online from the California Straw Building Association (http://www.strawbuilding.org/pages/main.php).

\section{Mushroom Production}

Rice straw is an effective substrate for mushroom production. Straw mushrooms (so called because they are grown on beds of rice straw) are a high-value crop that can be grown year-round. Following are the straw requirements for the mushroom-production market:

- Harvest with stripper headers to meet strawquality standards.

- Straw lengths must be greater than 8 inches.

- The supply of straw must be available yearround.

Wheat straw is the primary substrate used for mushroom production, and the estimated use for 1994 was 90,000 tons (CARB 1995). There is also interest in organic straws for organic mushroom production. 


\section{References}

California Air Resources Board (CARB), Department of Food and Agriculture, et al. 1995. Report of the Advisory Committee on Alternatives to Rice Straw Burning.

California Rice Commission. 2009. Environmental and conservation balance sheet for the California rice industry. Available online: http://www.calrice.org/Environment/Balance+Sheet/Chapter+4+-+Air+Quality.htm

Nader, G. A., and P. H. Robinson. 2000. Rice straw utilization by cattle. Rice Research Board Annual Report. Available online: http://www.carrb.com/00rpt/StrawCattle.htm

Nader, G. A., and P. H. Robinson. 2004. Defining the forage variability in rice straw. Rice Research Board Annual Report. Available online: http://www.carrb.com/04rpt/2004NaderRU-5.pdf

Nader, G. A., J. Williams, and R. Ingram 1998. Rice residue for use as cattle feed. California Rice Research Board $30^{\text {th }}$ Annual Report.

National Research Council. 1996. Nutrients requirements of beef cattle. National Academy Press, Washington, DC.

Summer, M. D., and J. Williams. 2001. Developing engineering data on rice straw for improvement of harvesting, handling, and utilization. Proceedings: Rice Straw Management Update. UCCE, Yuba

\section{For More Information}

You will find related information in other publications, slide sets, CD-ROMs, and videos from UC ANR.

To order products or download free publications, visit our online catalog at http://anrcatalog.ucdavis.edu. You can also place orders by mail, phone, or FAX, or request a printed catalog of publications, slide sets, CD-ROMs, and videos from

University of California

Agriculture and Natural Resources

Communication Services

1301 S. 46th Street

Building 478 - MC 3580

Richmond, California 94604-3427

Telephone: (800) 994-8849 or

(510) 665-2195

FAX: (510) 655-3427

E-mail:danrcs@ucdavis.edu

An electronic version of this publication is available on the ANR Communication Services website at http://anrcatalog.ucdavis.edu.

Publication 8425

ISBN-13: 978-1-60107-717-2

\section{UCER}

REVIEWED This publication has been anonymously peer reviewed for technical accuracy by University of California scientists and other qualified professionals. This review process was managed by the ANR Associate Editor for Agronomy and Range Sciences.

(C) 2010 by The Regents of the University of California Agriculture and Natural Resources.

All rights reserved.

The University of California prohibits discrimination or harassment of any person on the basis of race, color, national origin, religion, sex, gender identity, pregnancy (including childbirth, and medical conditions related to pregnancy or childbirth), physical or mental disability, medical condition (cancer-related or genetic characteristics), ancestry, marital status, age, sexual orientation, citizenship, or service in the uniformed services (as defined by the Uniformed Services Employment and Reemployment Rights Act of 1994: service in the uniformed services includes membership, application for membership, performance of service, application for service, or obligation for service in the uniformed services) in any of its programs or activities.

University policy also prohibits reprisal or retaliation against any person in any of its programs or activities for making a complaint of discrimination or sexual harassment or for using or participating in the investigation or resolution process of any such complaint. University policy is intended to be consistent with the provisions of applicable State and Federal laws.

Inquiries regarding the University's nondiscrimination policies may be directed to the Affirmative Action/Equal Opportunity Director, University of California, Agriculture and Natural Resources, 1111 Franklin Street, $6^{\text {th }}$ Floor, Oakland, CA 94607, (510) 987-0096. For information about obtaining this publication, call (800) 9948849. For downloading information, call (530) 754-3927.

To simplify information, trade names of products have been used. No endorsement of named or illustrated products is intended, nor is criticism implied of similar products that are not mentioned or illustrated.

web-10/10-WJC/RW 